\title{
John Calvin and the Reformed tradition on the jurisdiction of the church
}

\author{
P. Coertzen
}

Department of Ecclesiology

University of Stellenbosch

STELLENBOSCH

E-pos:pc@maties.sun.ac.za

Abstract

John Calvin and the Reformed tradition on the jurisdiction of the church

John Calvin's view on the power of jurisdiction in the church, as he writes about it in the Institutes, is expounded in this article. Firstly, attention is given to the spiritual authority of the church, followed by an exposition of the power of the church to exercise jurisdiction. Lastly the current situation in Reformed circles on the jurisdiction of the church is discussed.

\section{Introduction}

Although Calvin himself concedes that because the church has the authority to make laws, many traditions in the church have come into being. According to Calvin these traditions tend to act like nooses with which poor souls are often strangled and suffocated (see Institutes 4.10.1). This does not, however, mean that Calvin does not allow for power and its various manifestations in the church.

It remains a problematic issue - even today - that followers of John Calvin in Reformed churches often oppose the power of jurisdiction in the church, or at least do not do very much about it. In this article I would like to argue that people who oppose the power of jurisdiction in the church, and yet call themselves followers of John Calvin do not understand him correctly. For the viewpoint of Calvin I will, for the purpose of this article, concentrate on what was written in the Institutes. Future research in this regard will also have to take into account other sources which contain his thoughts in this regard. 


\section{Calvin on the spiritual authority/power of the church}

When Calvin writes about the spiritual authority/power of the church he starts off by saying that the power of the church resides partly in individual bishops, and partly in councils, either provincial or general. At this point in the Institutes he does not elaborate on the relationship between the individual bishop and the councils. In chapter 11.4 of the same book he emphasises that the power of jurisdiction can not be administered by the decision of one man but, with reference to 1 Corinthians 5:4-5, it must be administered by a lawful assembly. Once again Calvin's concept of a lawful assembly will have to be established through further research. The principle, however, of church government by a number of persons, rather than by one person alone is emphasised as is also the case in 4.3.15 and 4.4.10 and 11.

For Calvin the power/authority of the church consists in either doctrine, which he discusses in the Institutes 4.8; or in jurisdiction, on which he writes in 4.11; or in the power to make laws, which he discusses in 4.10. Doctrinal power includes two aspects, namely the authority to lay down articles of faith and the authority to explain them (Institutes 4.8.1).

This power of the church in its three parts implies a spiritual power, which must be distinguished from worldly power and is proper to the church (Institutes 4.8.1.) Also see the translations of Simpson $(1430,4)$, Battles (1149), Calvyn (1991) and Calvin (1950). This spiritual power is necessary for the church, good for the church, right for the church.

Calvin also reminds his "pious readers" that they should remember to link that which is taught about the power of the church to the purpose for which it is given, namely for the building up of the church and not for its destruction. This requires that those who use the power lawfully should regard themselves as being no more than servants of Christ, but at the same time to be servants of the people in Christ (1 Cor. 4:1). The only way to build up the church implies that ministers themselves attempt to preserve Christ's authority. This can only be secured if what Christ received from the Father, namely that $\mathrm{He}$ is the only schoolmaster of the church, be left to him. The words of Matthew 17:5, "Hear Him" must be kept intact (4.8.1).

Calvin also stresses that while the power of the church must not be manifested grudgingly, it at the same time, must be kept within definite limits. By doing this it will be assured that the power will not be drawn hither and thither according to the whims of men. If men are simply granted such power as they are disposed to take, it can very easily fall into tyranny, something that should be very far from Christ's church. 
(4.8.1). With this in mind Calvin turns to the description of power that the prophets and apostles gave. From their description it is clear that whatever authority and dignity the Spirit accorded to either priests, prophets, apostles or their successors it was never given to them personally but to the ministry to which they have been appointed or to the Word whose ministry was entrusted to them. They had no authority to teach or to answer except in the name and Word of the Lord. They were enjoined not to bring anything of themselves but only to speak from the Lord's mouth (4.8.2).

In 4.7.6 Calvin points out that the power of the church can be grouped under four headings, namely the ordination of bishops, the calling of councils, the hearing of appeals or jurisdiction and motions of chastisement or censure. During the course of time it happened that the Roman see advanced itself to usurp these powers for itself over other churches. For instance when Athanasius, the then chief defender of the orthodox faith, was expelled from his see it compelled him to come to Rome for jurisdiction. This and other similar cases led to the situation that Rome was granted much authority in issues of jurisdiction. Unfortunately people started appealing to Rome to flee lawful judgments within their own churches. "And the Roman bishops received these appeals more avidly than they should have, because it seemed a form of extraordinary power to meddle in business far and wide" (4.7.5).

\section{The power of the church to exercise jurisdiction}

Regarding the power to exercise jurisdiction, Calvin inter alia stresses the following aspects:

- Calvin views the ecclesiastical power to exercise jurisdiction (potestas diakrite) as the most important power which a well ordered church (state) has (4.11.1).

- The jurisdiction of the church pertains to morals (4.11.1)

- Just as no city or township can function without magistrate and polity so the church of God needs a spiritual polity. This polity is quite distinct from civil polity although it does not hinder or threaten it but rather greatly helps and furthers it. In order to preserve the spiritual polity of the church it is necessary for the church to have the power of jurisdiction. The jurisdiction of the church is nothing else but an order frame to preserve the spiritual polity of the church. If the church does not want to make void the promise of the keys or banish excommunication, solemn warnings and such things, it is very necessary that the church should have jurisdiction and also use it (4.11.1). 
- In order to exercise the power of jurisdiction Calvin points out that the early church had courts of judgment to deal with the censure of morals, investigate vices and to exercise the office of the keys. Calvin subscribes to these practices in the early church and for him it is very important that no admonition or correction be made without an investigation of the cause, and to do that, some court of judgment and order of procedure are necessary (4.11.1). In the Institutes Calvin does not spell out his detailed views on the church courts of judgments, their ways of investigation or the procedures that they had to follow. His detailed views on this will have to be established from other sources which do not fall within the scope of this article.

What is very important for Calvin and which has already been mentioned in this article but which specifically applies to the jurisdiction of the church is that the administration of justice - i.e. the exercising of jurisdiction by the church - must not be the function of an individual. In the early church the jurisdiction of the church was never in the hands of one man to do as he pleased. The power of jurisdiction was in the hands of the assembly of elders. When Cyprian mentions those through whom the power was exercised in his day he associates the entire clergy with the bishop. In other passages of his work he shows the clergy as so governing that the people were not excluded from deliberations (4.11.6). According to Calvin the common and customary practice in the early church was that the jurisdiction of the church had to be exercised through the senate of the presbyters of whom there were two kinds - those ordained to teach and the others to be censors of morals. Unfortunately this institution degenerated in the early church and already in the time of Ambrosias the clergy alone sat in ecclesiastical judgments. Calvin calls this a wicked misdeed that one man, transferring the common power to himself, both opened the way to tyrannous license and seized from the church what belonged to it, and suppressed and dissolved the assembly ordained by Christ's Spirit (4.11.6). Later the bishops delegated the power of jurisdiction, which they had claimed for themselves, to others. So-called "officials" were created to exercise the function of jurisdiction. This leads Calvin to write "If there were no other evil, with what impudence do these people dare call a brawling court a 'tribunal of the church'" (4.11.7). Once again Calvin affirms the necessity of tribunals in the church in order to exercise its power of jurisdiction. It is, however, very important that these tribunals must not concern themselves with the litigation of earthly matters; they must exercise a spiritual jurisdiction.

In the Institutes 4.12 where Calvin writes about the discipline of the church he points out that the discipline in the church - which he finds very necessary - depends on the power of the keys and then also upon 
spiritual jurisdiction (4.12.1). In the previous chapter of the Institutes (4.11.1, note 1 and 4.11.5-6) he pointed out that the power of the keys referred to discipline and excommunication as a part of jurisdiction.

Calvin finds the Scriptural foundation for the courts of judgment in the church in 1 Corinthians 12:28 and Romans 12:8 where Paul mentions the office of ruling. According to Calvin Paul is not addressing the magistrates but "those who were joined with the pastors in the spiritual rule of the church" (4.11.1). He finds further proof of this in 1 Timothy 5:17 where Paul, according to Calvin, distinguishes two kinds of presbyters - those who labour in the Word, and those who do not carry on the preaching of the Word, yet rule well. For Calvin the latter kind of presbyter was appointed to supervise morals and to use the whole power of the keys (4.11.1).

For Calvin the power of jurisdiction in the church is given to exercise the office of the keys. He goes so far as to say that "this power depends entirely upon the keys which, in the eighteenth chapter of Matthew, Christ gave to the church" (4.11.1). According to Calvin, Matthew 18:15-18 forms the Scriptural ground for church courts which must exercise the power of jurisdiction. In those verses Christ commands that those who are contemptuous of private warnings should severally be warned in the name of the people. However, if they persist in their stubbornness, Christ teaches that they should be cut off from the believers' fellowship. All of this cannot happen without investigation of the cause. This investigation, as has been said, requires some court of law and order of procedure. In these verses Calvin sees the implication that the power of jurisdiction of the Sanhedrin is transferred to the future flock of Christ (4.11.1).

For Calvin Matthew 18:15-18 is the foundation for the ecclesiastical power of jurisdiction. He, however, does not see it as a foundation for the doctrinal authority of the church. For the last he refers to Matthew 16:19 and John 20:23 both of which also deal with the power of binding and loosening (4.11.1). In the case of Matthew 16:19 and John 20:23 Calvin concludes that in those passages the power of the keys to forgive and retain sins and to bind and to loosen is simply the preaching of the gospel. With regard to men it is not so much power as ministry. Christ did not actually give this power to men but to his Word, of which he has made men ministers (4.11.1).

In the case of Matthew 18 it has to do with the discipline of excommunication which is entrusted to the church. Although there are many similarities between Matthew 18 and 16, such as that they both contain general statements, both deal with the same power of binding and 
loosening and both refer to the same command and the same promise. They, however, differ in that Matthew 16 is concerned with the preaching which ministers of the Word execute while Matthew 18 applies to the discipline of excommunication which is entrusted to the church (4.11.2). In the case of Matthew 18 it is the church who binds the person that she excommunicates. The church does not cast him into everlasting ruin and despair but binds him in that it condemns his life and morals and already warns him of his condemnation unless he should repent. On the other hand, the church loosens him whom it receives into communion for it makes him a sharer of the unity which it has in Christ Jesus. So that no man will stubbornly despise the judgment of the church or think immaterial of it, thinking that he has been condemned by the vote of the believers, the Lord testifies that such judgment by believers is nothing but the proclamation of his own sentence, and whatever they have done on earth is ratified in heaven (4.11.2).

For Calvin the distinction between civil and ecclesiastical jurisdiction is very important. Unlike civil jurisdiction the church does not have the right of the sword to punish or compel, nor the authority to force. It cannot inflict imprisonment or any of the other punishments which the civil magistrate has at his disposal. The church does punish a sinner against his will - according to Calvin - but brings him to professing his repentance in a voluntary chastisement. The church cannot assume what is proper to the magistrate and the magistrate cannot execute what is carried out by the church. The magistrate can imprison a person because he is a fornicator and the laws, the magistrate and outward justice will be satisfied. The magistrate, however, does not require repentance from the perpetrator. The same person, without repentance, cannot be received to the Lord's Supper because he will bring injury to Christ and his sacred institution (4.11.6).

The distinction between civil and spiritual jurisdiction was also not just a temporary distinction. For Calvin the words in Matthew 18 set a permanent order for the church. In Matthew 18 Christ indicates that his church cannot go without the spiritual jurisdiction which it had from the beginning (4.11.4).

The aim of ecclesiastical jurisdiction is that offences be resisted and any scandal that has arisen be wiped out. In the exercise of this it must be completely separated from the right of the sword. Very important also is the fact that, other than the jurisdiction of the magistrate, the jurisdiction of the church must never be administered by the decision of one man alone but always by a lawful assembly. 


\section{The current state of affairs in Reformed ecclesiastical jurisdiction}

After we have seen what Calvin had to say on the power of the jurisdiction of the church let us now turn to a few Reformed theologians and churches, followers of John Calvin, to see what their views on the jurisdiction of the church are and the way in which it is exercised.

\subsection{F.I. Rutgers}

F.I. Rutgers, a leading church law theorist of the period of dissension from the Hervormde Church of the Netherlands by the end of nineteenth century, had the following to say in his lectures on the Dordrecht Church Ordinance adapted and published in 1918 by a pupil of his, J. de Jong: the provisions in a church's ordinances must never become the equivalent of a kind of "Statutes of Criminal Procedure". The church ordinances must not become a document listing all possible instances of disciplinary actions, or indicating which disciplinary measures should apply in each particular instance, or what the procedure or course of the investigation should be.

Er kan geen code pénal voor kerkelijke tucht gemaakt worden. Het doel van de tucht eischt de grootste speelruimte in de toepassing, geen regelen voor vaste practijk. Indien maar de beginselen vasstaan en op ieder geval worden toegepast, dan wordt de kerkelijke tucht alleen recht gebruikt. Dus geen wetbepalingen in de kerkordening (De Jong, 1918:11).

[There can be no penal code drawn up for church discipline. The aim of church discipline requires the maximum of freedom in its application, not hard and fast rules. Only if the principles are known and applied to each particular case is church discipline being rightly applied. Therefore no legal regulation in a church ordinance.]

At the same time Rutgers states that those who have to apply church discipline have certain principles they must maintain as law. He refers to these as an awareness of the law in people without their ever having necessarily studied law. "(Zij) vinden zelf 'Anklang' in de menschelijke consciëntie en het zedelik gevoel” (De Jong, 1918:65).

[They find resonance in the human conscience and moral feeling.]

According to Rutgers, examples of these "legal" principles are:

... het beginsel: niemand ongehoord te veroordelen. leder gevoelt hiervan de waarheid en het recht, ook al staat het niet in de kerkordeninge. Dit is een algemeen beginsel, dat altijd gelden moet; de toepassing hiervan hangt van omstandigheden af. Een tweede zoodanig beginsel is, dat niemand in zijn eigen zaak, of in eene zaak, 
waarbij hij naaste betrekkingingen heeft, bv. vader of kinderen, een volkomen betrouwbaar getuigenis kan afleggen (De Jong, 1918: 65).

[... the principles are that nobody must be judged without a hearing. Everybody recognises the right and truth of this even though it is not written in a church order. It is a general principle that must always apply; its application depends on the circumstances. A second principle is that nobody can give reliable testimony in a case in which he himself or a close family member, e.g. a father or children, are involved.]

It seems as if the principles Rutgers refers to and which are inborn, are actually the so-called rules of natural justice, which of course play an important role in the jurisdiction of the church. Rutgers makes a strong plea for the application of these rules to become established custom in the church through usage. It may happen, he says, that an elder in the rural areas does not know about the application of these principles, or that he cannot make a sound judgement due to a lack of clear insight. In such a case church custom will be of great help:

Dan moet het gaan, zooals de zaak vroeger reeds behandeld is, terwijl langzamerhand een soort gewoonterecht zich vormt (De Jong, 1918: 65).

[Then it must be dealt with as in an earlier case, and gradually a kind of custom is established.]

In cases of doubt one may always call upon the Classis. The question is naturally whether customary usage as such is a good thing for the church. Does it not create too much room for arbitrariness in church investigations. It is also an open question whether customary usage as such allows sufficient room for the dynamic development of law and church law in particular.

\subsection{Martin Monsma}

Martin Monsma, in his and Izerd van Dellen's revised commentary (published 1967) on the new Church Order of the Christian Reformed Church (1965), supports Rutgers's viewpoint. He points out that there are certain principles in the church ordinance that must be applied in the administration of discipline.

The Church Order does not specify in detail how investigations are to be conducted; how long one should be disciplined before the final step of excommunication is taken; which specific sins are worthy of discipline, etc. The Church has no penal code, for the Church does not seek to administer external punishments, but the Church seeks to save the sinner and to promote the glory of God. To attain these ends each case must be dealt with according to its particular circumstances, as 
soon as the end in view has been gained ecclesiastical discipline ceases (in Van Dellen \& Monsma, 1968:289).

But when Monsma comes to the statement in article 82 of the Church Order which provides that "[d]isciplinary measures shall be applied only after adequate investigation has been made and the member involved has had ample opportunity to present his case", another perspective emerges when he writes:

When consistory finds that a certain charge or report requires investigation, it should do its utmost to carry on the investigation impartially. He who is accused must receive ample opportunity to defend himself if he denies guilt. He may defend himself in person, orally or by written statement (Van Dellen \& Monsma, 1968:305).

He continues by pointing out that, in addition to the insistence on impartiality and ample opportunity for self-defence, that the accused could even be provided with assistance in stating his case. The assistance must come from a reliable and sincere Christian who will give a fair version of the facts and be prepared to abide by the rules of the church assembly concerned. Furthermore, the assembly must hear only reliable evidence, which means that witnesses must be irreproachable members of the church who must be beyond criticism for their honesty or they must be reliable people who are not members of the church. The investigating body must also make certain that they weigh the evidence very carefully and not come to a hasty decision. The investigation must be conducted in a dignified manner in an attitude of prayer and absolute impartiality. They must also guard against being excessively technical. "Each case should be investigated not according to certain set and highly technical rules but rather freely, as fairness and sanctified common sense may indicate for every specific case" (Van Dellen \& Monsma, 1968:30653066). Monsma also points out that there are certain rules for dealing with appeals, although at that stage there were no such fixed rules in the Christian Reformed Church.

It thus seems that, on the one hand, Monsma subscribes to Rutgers's view that the church does not work with a penal code in a disciplinary process. A penal code would imply that there is a fixed correlation for the church between infringement and punishment. On the other hand, Monsma states very clearly, just as Rutgers does, that there are very clear requirements in a disciplinary process to which the church must comply. The rejection of disciplinary processes as being equivalent to a penal code thus clearly does not mean for Monsma that there are not specific procedural requirements for the jurisdiction of the church that have to be complied with. 


\subsection{The Christian Reformed Church North America}

In 1971 the synod of the Christian Reformed Church North America recorded the following on the status of procedural rules for jurisdiction in that church: "Rules of procedure are not mere technicalities but basic principles for right and decency and good order" (Acts of Synod 1971:158, in De Ridder \& Hofman, 1994:167). In 1977 the Synod of the Christian Reformed Church expanded article 30 of the Church Order to include the following provision: "When written charges requiring formal adjudication by an ecclesiastical assembly are made, the relevant provisions of the Judicial Code shall be observed". In the 1994 issue of the Church Order the relevant article was changed to read: "If invoked, the Judicial Code shall apply to the processing of appeals and written charges" (Church Order, 1994, Christian Reformed Church in North America, art. 30).

There was thus a whole process of development in the Christian Reformed Church which ultimately led to the creation of a Judicial Code for this Church. To explain this code the 1977 Synod mentioned the following considerations:

- The Code would lead to greater uniformity in the denomination when charges or allegations have to be adjudicated.

- It would help to protect the rights of those involved in investigations and decisions: "The Judicial Code will help to insure just treatment of those who are involved in the judgements and decision of the Church".

- The Scriptures require that provision be made for impartial administration of justice or adjudication between the people of the Lord.

- Church assemblies must deal with church-related matters in a way appropriate for the church. Without effective procedural guidelines it is often very difficult for the church to deal with important matters properly.

- The Judicial Code wishes to create the procedural matrix within which the law of love may be fulfilled. In this respect one can refer to James 2:1, 8 and 9 (Brink \& De Ridder, 1980:133-134). Verse 1 reads: "Are ye not then partial in yourselves, and are become judges of evil thoughts?" Verse 8: "If ye fulfil the royal law according to the scripture, Thou shalt love thy neighbour as thyself, ye do well". Verse 9: "But if ye have respect to persons, ye commit sin, and are convinced of the law as transgressors". 
The Judicial Code of the CRC makes very clear provision for written complaints and answers, the right to be heard and represented, the specification of charges, a clear description of proper procedures for the church council, the classis and an arbitration procedure for the synod. Articles 22-24 of the Code make provision for a Judicial Code Commission consisting of nine members appointed for a period of three years and which must, among other things, advise the annual synod on appeals and charges (CRC Church Order, 1994: art. 22-24).

\subsection{Nauta (Gereformeerde Kerken in Nederland)}

D. Nauta, author of Verklaring van de Kerkorde van de Gereformeerde Kerken in Nederland, writes in this regard on the power of church assemblies to take decisions in disciplinary measures against office-bearers:

Het zal duidelijk zijn, dat hiermede aan de kerkelijke vergaderingen een verstrekkende bevoegdheid wordt verleen. Er zijn geen nauwkeurige algemene voorschriften, waaraan zij zich moet houden bij het nemen van de bedoelde beslissing, bijvoorbeeld in welke gevallen het niet geoorloofd zou zijn verder te gaan dan tot het uitspreken van een schorsing of onder welke voorwaarden het toegestaan zou zijn terstond te besluiten tot de algehele ontzetting uit het ambt. Het zou stellig niet makkelijk zijn een aantal voorschriften van die aard op te stellen, omdat het zou noodzaken tot het geven van onderscheidingen ten aanzien van gevallen, die zich ter zake kunnen voordoen. Aan de ander kant zou iemand op het opstellen daarvan kunnen aandringen met beroep op de rechtzekerheid der ambtsdragers (Nauta, 1971:408-409).

[It is clear that with this church meetings have a far-reaching authority granted to them. There are no meticulous and general prescriptions to which they must be kept for the taking of a decision, i.e. in which cases they are not allowed to go further than suspension or under which conditions it is allowed to decide immediately to put someone out of office. It would not be easy to draw up prescriptions because it would be necessary to draw up certain prescriptions for certain cases. On the other hand, someone could ask for this with reference to the protection of the rights of office-bearers.]

Ultimately Nauta prefers not to compile specific rules for the security and protection of rights in the jurisdiction of the church because, he says, in this instance policy has been entrusted to the church assemblies and they have the freedom to take into account all the circumstances of a specific case and to deliver a judgement that is as closely linked as possible to the requirements of the case and the interests of the congregation (Nauta, 1971:409).

So far the answer of three members of the overseas family of Reformed churches or from leading church law theorists within these churches on 
the question of how churches should exercise their power of jurisdiction. It is important to note that the fear of a penal code in the church never meant that the protection of rights were not important for these churches. In the Netherlands the general feeling within the Gereformeerde Kerken up until a short while ago was that the formal protection of rights need not formally be written into a church order. Church councils dealing with investigations should in any case pay attention to the protection of rights. In the Christian Reformed Church of North America there has been a very definite development towards a formal Judicial Code. Furthermore it is important to note that the rules of procedure are not seen as mere technicalities but as "basic principles for right and decency and good order" (De Ridder \& Hofman, 1994:167). This obviously calls for theological reflection on these rules. Apart from the clear position of the Christian Reformed Church of North America it seems as if there is a certain hesitancy among Reformed Church politicians on the issue of how churches should exercise their power of jurisdiction. It is as if there is not the same clear conviction on this matter as we find with Calvin.

\subsection{South Africa}

As far as Reformed church government in South Africa is concerned the power of jurisidiction of the church is largely accepted as a matter of fact, be it with some resistance. Very little theological reflection is found in this regard.

\section{- T.H.N. Sadler}

T.H.N. Sadler writes in a relatively short paragraph with regard to disciplinary investigations in the Dutch Reformed Church that they must firstly comply with the requirements laid down in the Church Order regarding the composition of the body doing the investigation, the relevant jurisdiction of this body and the correct procedures that must be followed. Secondly, in any investigation there must be adhered to the rules of natural justice, which he then explains briefly (Sadler, 1979:124-125).

\section{- B. Spoelstra}

In his work Gereformeerde kerkreg en kerkregering1 B. Spoelstra (1989: 399-401) of the Reformed Churches in South Africa (GKSA) deals with the disciplinary investigation of church councils. He accepts the fact of the jurisdiction of the church without really giving an account as to why it is something that is necessary in Reformed church government.

1 All English translations of quotations from Spoelstra (1989) are those of the author of this article. 
Spoelstra notes that there are a number of important issues with regard to the procedural rules and the protection of rights in the church:

The complainants (witnesses) do not have to come from the congregation nor even be believers. But they must be personally known to the church council and as a rule be willing to assist the church council in dealing further with the matter.

"It is always recommended that the 'witnesses' (complainants) appear before the church council themselves and answer questions from the elders" (p. ). If a written charge mentions witnesses, the chairman and church secretary must determine beforehand from the witnesses whether they support the charge and give evidence in the arbitration.

The complainant is not mistrusted, but the church council as well as the person facing the charge must be protected in terms of articles 72-74. There is a danger that the church council may accept a written charge and afterwards may find that the procedures in terms of articles 72-74 have not been complied with. This jeopardises the legal validity of actions that affect a person's name and honour (Spoelstra, 1989:399).

Spoelstra also notes that a charge must first be properly tabled in terms of article 74 of the Church Order; the church council must then determine precisely the nature of the charge. A provisional investigation should preferably be conducted in the full church council so that all the elders are fully informed before they assist in the judgment.

A commission is not in any sense a church council. The person charged can ask for a commission, but always retains the right to be present where evidence is being submitted about him, provided the witness can behave with the proper reverence. The church council must make a finding only after the facts have been determined, otherwise they must be satisfied with a non liquet and give the benefit of the doubt to the person charged (Spoelstra, 1989:400).

If a person will not or cannot appear before the church council, a commission of at least three members (witnesses) can undertake the investigation. The danger, however, is that in this respect the commission's report will usually form the basis of the church council's actions. That is why great care must be taken to ensure that the report presents both sides of the case impartially. The commission must clearly state, for example, what the charge entails, what warnings have been issued to the sinner and how he reacted to them, what his defence entailed, and what the current state of affairs is.

The commission must report to the church council without adding any comments, suggesting findings, or making recommendations, so that the church council can make its decisions only once the case has been 
fully presented from both sides. At most the commission presents a case and does not finalise it (Spoelstra, 1989:400).

In addition to various other matters, Spoelstra also notes that, although these days a commission of enquiry is used often, the right remains for anyone to present and defend his case in the church council. This does not happen always as Spoelstra also states that commissions usually do the work upon which the church council simply places its seal of approval, to which he adds: "This working method jeopardises the honour, dignity, care and honesty of the church council. The church council must be in a position to check and rectify the work of the commission" (Spoelstra, 1989:400). The "right" to which Spoelstra refers is not more fully defined, but it seems to refer to the rules of natural justice that apply in investigations by quasi-judicial bodies such as a church council. Spoelstra also makes provision, for a variety of reasons, for a person charged to ask for assistance in stating his case. The Church Order as such does not have anything to say on this. "This is after all not secular administration of justice where a whole series of laws, provisions and rules have to be complied with, making juristic assistance essential" (Spoelstra, 1989:401). The church council can, however, grant the request if such assistance would promote the objectives of the disciplinary hearing; but the church council can also refuse or withdraw such assistance if it is being misused in their opinion (Spoelstra, 1989:401). The possibility arises of this assistance being granted in a completely arbitrary way if there is not some way or other of making it a more fixed arrangement. There is also an element of arbitrariness in Spoelstra's view that the church council is not bound to the original wording of the charge in its investigations, but that they can reformulate it during the course of the investigation to correspond more or less to the original statement. The complainants may be implicated by the person charged on good grounds. A church council may even terminate the hearing of a case if there is any hope of reconciliation through arbitration (Spoelstra, 1989:401).

\section{Conclusion}

Lastly a few conclusions are drawn concerning Calvin's views on the power and jurisdiction of the church.

- Quite often in our times people do not want to hear of such things as the power and jurisdiction of the church. These matters are seen as in contrast with the essence of the church. Calvin did not hesitate to indicate that there are such things as ecclesiastical power or authority and that part of that authority is the power of jurisdiction. Very important is that Calvin based his views about authority and jurisdiction 
on the Word of God. As a matter of fact, for Calvin the power of jurisdiction in the church was necessary to preserve the spiritual polity of the church.

- Calvin also does not hesitate to acknowledge, on biblical grounds, the necessity of courts of judgment in the church. He found these in the early church and also saw how they deteriorated during the course of history. In his time jurisdiction became the function of officials in the church. This deterioration does not stop Calvin from acknowledging the necessity of courts in the church for the exercising of its power of jurisdiction.

- Although he does not elaborate on it in the Institutes Calvin clearly states that the exercise of the jurisdiction of the church necessitates courts of judgments and orders of procedure through which investigation can be made as to the causes for admonitions and corrections. Further research needs to be done as to how Calvin himself in practice worked out and implemented the courts of judgment and the orders of procedure.

- Calvin is adamant that ecclesiastical jurisdiction must never be administered by the decision of one person alone. It must always be done by a "lawful assembly". Calvin bases this requirement on biblical grounds. In the requirements of a lawful assembly, procedures of order, and no admonitions or corrections before investigation, we have indications that Calvin stood for a just process in the exercising of the jurisdiction of the church. However, these requirements are not worked out in the Institutes. Further research will have to be done in this regard.

- It seems as if the mentioned requirements for the just administration of the jurisdiction of the church did not receive much attention in Reformed circles during the period after Calvin. It is only in the last decades that we find Reformed churches paying attention to these matters, even if it is with hesitancy in many cases.

There is certainly much to say for going back to Calvin to hear what he said but also to see what he did with regard to the jurisdiction of the church.

\section{Bibliography}

BATTLES, FORD LEWIS. 1980. Analysis of the Institutes of the Christian Religion of John Calvin. Grand Rapids : Baker Book House.

BRINK, W.P. \& DE RIDDER, R.R. 1980. Manuel of Christian Reformed Church Government. Grand Rapids, Mi : CRC Publications. 
CALVIN. 1950. Institutes of the Christian Religion. Edited by John T. McNeill. Translated by Ford Lewis Battles. Philidelphia : The Westminster Press.

CALVYN, J. 1991 [1559]. Institusie van die Christelike godsdiens. Vertaal deur H.W. Simpson met medewerking van C.M.M. Brink. Potchefstroom : CJBF.

CHRISTIAN REFORMED CHURCH IN NORTH AMERICA. 1994. Church order \& rules for synodical procedure. Grand Rapids, Michigan : CRC Publications.

DE JONG, J. 1918. Verklaring van de Kerkenordening van de Nationale Synode van Dordrecht van 1618-1619. College-voordrachten van Prof. F.L. Rutgers over Gereformeerd Kerkrecht. Deel 4 Artt. 71-86, van de Censuur en Kerkelijke Vermaning. Rotterdam : Libertas Drukkerij.

DE RIDDER, R.R. \& HOFMAN, L.J. 1994. Manuel of Christian Reformed Church government. Grand Rapids, Michigan : CRC publications.

NAUTA, D. 1971. Verklaring van de kerkorde van de Gereformeerde Kerken in Nederland. Kampen : Kok.

SADLER, T.H.N. 1979. Die kerklike tughandeling. 'n Ondersoek na die tughandeling in die gereformeerde kerkreg met besondere verwysing na die praktyk in die Nederduitse Gereformeerde Kerk. Pretoria : NG Kerkboekhandel.

SPOELSTRA, B. 1989. Gereformeerde kerkreg en kerkregering. 'n Handboek by die Kerkorde. Pretoria : Die Hammanskraalse Teologiese Skool van die Gereformeerde Kerke in Suid-Afrika.

VAN DELLEN, I. \& MONSMA M. 1968. The revised church order commentary. A brief explanation of the church order of the Christian Reformed Church. Grand Rapids : Zondervan Publishing House.

\section{Kernbegrippe:}

geestelike gesag

gereformeerde teologie

kerklike jurisdiksie

kerkreg en kerkregering

\section{Key concepts:}

church polity and church government

jurisdiction of the church

Reformed theology

spiritual authority 